\title{
KONSEP DIRI REMAJA KRISTEN DALAM MENGHADAPI PERUBAHAN ZAMAN
}

\author{
Selvy Iriany Susanti Dupe \\ Sekolah Tinggi Teologi Injili dan Kejuruan Kupang \\ selvyirianysusanti@gmail.com
}

\begin{abstract}
The ever-expanding changes times have an impact on many people even more on the lives of Christian teens. The teenage phase is a pretty hard time to deal with because of many influences around both positive and negative. This phase is also in which a person's mind begins to form and depends on the circumstances surrounding them. This study aims to provide an overview of the self-concept of Christian teens in the face of changing times that continue to develop. Researches use a literature study approach to find the main picture of the research in question. The results showed that Christian youth in facing the changing times needed God's wisdom in this world and needed to be followed by the right example of life. In addition, it is necessary to present the right figures and be the right role models, both from parents and the church (youth servants, servants of God/pastors) so that there is a role model for adolescents who help them live a wiser and more responsible life even if it occurs changing times that have their own impact.
\end{abstract}

Keywords: self concept, christian teenagers, changing times

\begin{abstract}
Abstrak
Perubahan zaman yang terus berkembang tentu memiliki dampak bagi banyak orang terlebih lagi pada kehidupan remaja Kristen. Fase remaja adalah masa-masa yang cukup sulit dihadapi dikarenakan banyaknya pengaruh di sekitar baik secara positif dan juga negatif. Di fase ini pula pola pikir seseorang mulai terbentuk dan tergantung dari keadaan yang ada di sekitarnya. Penelitian ini bertujuan untuk memberikan gambaran tentang konsep diri remaja Kristen dalam menghadapi perubahan zaman yang terus berkembang. Peneliti menggunakan pendekatan studi pustaka untuk menemukan gambaran pokok penelitian yang dimaksud. Hasil penelitian menunjukkan bahwa remaja Kristen dalam menghadapi perubahan zaman, perlu hikmat Tuhan dalam dunia ini dan perlu diikuti dengan keteladan hidup yang benar. Selain itu, perlu menghadirkan tokoh-tokoh yang benar dan menjadi teladan yang benar, baik itu dari orangtua maupun gereja (pelayan remaja, hamba Tuhan/pendeta) agar ada role model bagi remaja yang membantunya dalam menjalani hidup dengan lebih bijak dan lebih bertanggungjawab sekalipun terjadi perubahan zaman yang membawa dampak tersendiri.
\end{abstract}

Kata Kunci: konsep diri, remaja kristen, perubahan zaman 


\section{Pendahuluan}

Apa yang terjadi dalam perkembangan dunia sekarang ini di satu sisi mengembirakan karena manusia memperoleh banyak kemudahan dalam banyak segi kehidupan. Misalnya saja manusia dapat mengakses berbagai macam informasi dari berbagai belahan dunia dalam waktu yang relatif singkat dengan adanya jaringan internet. Kemudian didukung dengan adanya ponsel canggih, manusia dapat menjangkau berbagai tempat dalam waktu yang lebih cepat dengan adanya kemajuan dan ketersediaan berbagai macam pilihan alat transportasi, dan berbagai macam kemudahan dalam hidup lainnya. Hal ini tentu saja patut disyukuri. Namun di sisi yang lain manusia juga tidak bisa menutup mata terhadap berbagai dampak yang ditimbulkan, salah satunya berdampak pada bagaimana seseorang memandang dirinya.

Informasi yang tidak terbendung menyebabkan sebuah informasi dapat dengan mudah disebarkan dan diterima. Misalnya saja informasi berkaitan dengan produk tertentu yang diiklankan melalui media massa. Sebuah produk kecantikan yang cenderung menampilkan penilaian tentang kecantikan yang ideal dengan ciri-ciri tertentu seperti langsing, kulit putih, rambut lurus, dan lain sebagainya. Akibatnya terbentuklah konsep tentang yang cantik dan yang tidak cantik berdasarkan apa yang diserukan melalui iklaniklan tersebut.

Remaja sebagai kelompok yang sedang berada dalam masa topan dan badai (storm and stress) ${ }^{1}$ sesungguhnya sangat membutuhkan arahan yang jelas. Mereka berada pada masa dimana akan ada banyak pilihan-pilihan di sekitar mereka yang dapat mengganggu mereka dalam membentuk sebuah konsep diri yang benar. Konsep diri remaja perlu dibangun di atas dasar yang tepat, bukan karena kata iklan atau perkataan seseorang. Bukan juga karena pengaruh hal-hal lainnya. Akan tetapi khususnya sebagai remaja Kristen perlu landasan yang tepat dalam membangun konsep diri yang benar, yaitu Firman Tuhan. Konsep diri menurut Ariana dan Pramitasari yang dikutip oleh Mayang D. Anisa mendefinisikan sebagai sifat yang dinamis, artinya tidak luput dari perubahan. Ada aspekaspek yang bisa bertahan dalam jangka waktu tertentu, ada pula yang mudah sekali berubah sesuai dengan situasi sesaat.

Hasil penelitian menunjukan bahwa terdapat hubungan negatif antara konsep diri fisik dan kecenderungan kecemasan sosial pada remaja awal. ${ }^{2}$ Dalam masa pertumbuhan yang mencari jati diri, remaja cenderung menginginkan agar apa yang diinginkan dapat tercapai. Sehingga dampak yang ditimbulkan kurang baik, lalu memberontak. ${ }^{3}$ Masa remaja berada pada batas peralihan kehidupan anak dan dewasa. Tubuhnya tampak sudah dewasa, akan tetapi bila diperlakukan seperti orang dewasa, remaja gagal menunjukan kedewasaannya. Pengalamannya mengenai alam dewasa masih belum banyak karena ia sering terlihat pada remaja dengan adanya kegelisahan, pertentangan, kebingungan, dan konflik pada diri sendiri. ${ }^{4}$ Munculnya berbagai masalah remaja, umumnya berakar dari konflik dan krisis identitas yang terjadi di dalam dirinya. ${ }^{5}$ Saat ini menurut Davis dalam

${ }^{1}$ Syamsu Yusuf, Psikologi Perkembangan Anak Dan Remaja (Bandung: Rosdakarya, 2002), 184.

2 Mayang D. Annisa, “Hubungan Antara Konsep Diri Dengan Kecemasan Umum Pada Remaja Awal," Jurnal Psikologi 10, no. 2 (December 2017): 106-111.

3 Jonathan Matheus and Elisabet Selfina, "Peran Pembina Remaja Bagi Perkembangan Perilaku Remaja Di Gereja Kemah Injil Indonesia Tanjung Selor Kalimantan Utara," Jurnal Jaffray 13, no. 1 (January 2015): 1.

${ }^{4}$ Khamim Zakasih Putro, "Memahami Ciri Dan Tugas Perkembangan Masa Remaja," APLIKASIA: Jurnal Aplikasi Ilmu-ilmu Agama 17, no. 1 (2017): 25-32.

${ }^{5}$ Sadadohape Matondang, "Memahami Identitas Diri Remaja Dalam Kristus Menurut Efesus 2:1-10," Illuminate: Jurnal Teologi dan Pendidikan Kristiani 1, no. 1 (August 2018): 105-124. 
tulisannya Tensions of identity in a networked era: Young people's perspectives on the risks and rewards of online self-expression, remaja memikirkan representasi dirinya, mereka kehilangan diri mereka yang sebenarnya karena representasi online yang mereka tampilkan berbeda dari cara mereka berperilaku di dunia nyata. ${ }^{6}$

Keadaan seperti disebutkan di atas harus ditanggapi secara serius sebagai sebuah tantangan. Tetapi juga sebagai sebuah peluang untuk membentuk generasi ke depan yang tetap hidup di dalam takut akan Tuhan sekalipun mereka harus berhadapan dengan berbagai hal yang dapat menggoncang iman. Harapan bersama adalah mereka tetap diberi hikmat untuk mampu melawan berbagai godaan dunia, dan dengan keterlibatan semua pihak, terlebih Tuhan sendiri yang mampu memberi kekuatan untuk semua remaja mampu mengatasi segala persoalan kehidupan. Untuk itu, tulisan membahas bagaimana remaja Kristen memiliki konsep diri yang benar.

\section{Metode Penelitian}

Tulisan ini menggunakan pendekatan kajian kualitatif dengan studi pustaka. Menurut Sarosa yang dikutip oleh simon mendefenisikan penelitian kualitatif adalah penelitian yang mencoba memahami fenomena dalam setting dan konteks naturalnya. ${ }^{7}$ Kajian pustaka yang dimaksud ialah mengumpulkan materi penelitian dari berbagai sumber, baik sumber buku, jurnal, dan sumber lainnya yang mendukung pokok pembahasan dalam tulisan ini. Studi pustaka merupakan serangkaian kegiatan yang berkenaan dengan metode pengumpulan data pustaka, membaca, mencatat serta mengolah bahan penelitian. ${ }^{8}$ Buku-buku yang disadur adalah mengenai psikologi, kerohanian, dan juga jurnal ilmiah yang membahas persoalan gaya hidup masa kini. Melalui materi yang terkumpul tersebut, penulis akan menggabungkan pokok-pokok bahasan yang diperlukan serta melakukan analisis terhadap pokok pembahasan tersebut. Kemudian dilakukan deskripsi fakta-fakta tidak semata-mata menguraikan, melainkan memberikan pemahaman dan penjelasan. ${ }^{9}$

\section{Hasil dan Pembahasan}

\section{Remaja dan Perubahan Zaman}

Remaja dan perubahan zaman memang selalu identik dikarenakan dampak yang paling terasa dari zaman yang terus menerus berubah adalah masa remaja. Bertumbuh menjadi seorang remaja di dalam perubahan zaman seperti saat ini adalah sesuatu yang cukup sulit. Mengingat ada hal-hal yang baik dan buruk bercampur menjadi satu. Perubahan zaman yang dimaksudkan adalah adanya pergeseran-pergeseran atau perubahan-perubahan dari apa yang terjadi pada zaman/masa dahulu dengan apa yang terjadi pada masa sekarang ini. Terutama menyangkut perubahan yang terjadi dalam masyarakat. Perubahan seperti ini memang lebih sering dikenal sebagai perubahan sosial.

Perubahan sosial oleh Wilbert Moore didefinisikan sebagai perubahan penting dari struktur sosial dan yang dimaksud dengan struktur sosial adalah pola-pola perilaku dan

${ }^{6}$ Pamela Felita et al., "Pemakaian Media Sosial Dan Self Concept Pada Remaja," Jurnal Ilmiah Psikologi Manasa 5, no. 1 (2016): 30-41.

7 Simon, "Peranan Gereja Dalam Menghambat Laju Pertumbuhan Pemakai Narkoba," Jurnal Ilmiah Religiosity Entity Humanity (JIREH) 1, no. 2 (December 2019): 172-186.

${ }^{8}$ Dicky Dominggus, "Kemanunggalan Dalam Yohanes 15:7 Sebagai Misi Kontekstual Kepada Penganut Kejawen," VISIO DEI: JURNAL TEOLOGI KRISTEN 1, no. 2 (December 2019): 178-199.

${ }^{9}$ Ezra Tari and Rinto Hasiholan Hutapea, "Peran Guru Dalam Pengembangan Peserta Didik

Di Era Digital" 1, no. 1 (2020): 1-13, http://jurnalsttkharisma.ac.id/index.php/Kharis/article/view/1. 
interaksi sosial. Perubahan sosial adalah fenomena yang rumpil (sulit) dalam arti menembus ke berbagai tingkat kehidupan sosial, yang berbeda hanyalah tingkat perubahannya saja. Perubahan itu normal dan berlanjut, terjadi di berbagai tingkat kehidupan manusia mulai dari individual sampai ke tingkat dunia. ${ }^{10}$ Perubahan dalam keluarga yang terlihat universal adalah pemindahan sebagian besar fungsi keluarga kepada unit sosial lain seperti pemerintah, sekolah, dan badan usaha. ${ }^{11}$ Keluarga sebagai unit terkecil terkena dampak perubahan yang terjadi, dengan demikian anggota keluarga dalam hal ini remaja, pasti juga terkena dampak perubahan yang ada. Salah satunya dari sisi gaya hidup remaja.

Susanto mengartikan gaya hidup sebagai suatu perpaduan antara kebudayaan ekspresi diri dan harapan terhadap seseorang dalam bertindak yang berdasarkan pada norma-norma yang berlaku. ${ }^{12}$ Di sisi lain, Engel Blackwell dan Miniard mendefinisikan gaya hidup sebagai pola dimana orang hidup dan menggunakan uang dan waktunya. ${ }^{13}$ Jadi gaya hidup adalah pola hidup seseorang sehari-hari baik dalam hal berpakaian, makan-minum, bersikap, dan lainnya. Gaya hidup remaja sekarang tentu berbeda dengan zaman dulu. Perubahan gaya hidup remaja saat ini (tanpa mengabaikan bahwa masih ada sekian banyak remaja dengan prestasi dan perilaku yang baik) dipengaruhi oleh gaya hidup yang konsumtif, materialis, dan permisif.

\section{Gaya Hidup Konsumtif}

Kamus Besar Bahasa Indonesia mendefinisikan kata "konsumtif" sebagai bersifat konsumsi (hanya memakai dan tidak menghasilkan sendiri). ${ }^{14}$ Gaya hidup konsumtif atau konsumtifisme berarti individu atau masyarakat yang mempunyai keinginan untuk membeli atau menggunakan barang dan jasa yang kurang atau tidak dibutuhkan. Mereka membeli bukan dengan pertimbangan rasional atau bukan karena kebutuhan. Perilaku konsumtif adalah tindakan membeli barang bukan untuk mencukupi kebutuhan tetapi untuk memenuhi keinginan, yang dilakukan secara berlebihan sehingga menimbulkan pemborosan dan inefisiensi biaya. ${ }^{15}$ Anggasari menyebutkan perilaku konsumtif sebagai tindakan membeli barang-barang yang kurang atau tidak diperhitungkan sehingga pada akhirnya sifatnya berlebihan. ${ }^{16}$

Dengan demikian dapat disimpulkan bahwa gaya hidup konsumtif adalah perilaku membeli barang secara berlebihan bukan karena kebutuhan tetapi semata karena keinginan. Remaja yang terjebak dalam gaya hidup konsumtif rela mengeluarkan uang untuk menuruti segala keinginannya dan bukan karena kebutuhannya. Mereka rela mengeluarkan uang untuk membeli makanan, pakaian, perangkat elektronik, menonton film hanya untuk ajang pamer dan gengsi semata. ${ }^{17}$

${ }^{10}$ Roberth H. Lauer, Perspektif Tentang Perubahan Sosial (Jakarta: PT Rineka Cipta, 2001), 4-5.

11 Ibid. 440.

12 Susanto, Potret-Potret Gaya Hidup Metropolis (Jakarta: Kompas, 2001), 120.

${ }^{13}$ Sari Listyorini, “Analisis Faktor-Faktor Gaya Hidup Dan Pengaruhnya Terhadap Pembelian Rumah Sehat Sederhana (Studi Pada Pelanggan Perumahan Puri Dinar Mas PT. Ajisaka Di Semarang)," Jurnal Administrasi Bisnis 1, no. 1 (September 2012).

${ }_{14}$ Departemen Pendidikan Nasional, Kamus Besar Bahasa Indonesia (Jakarta: PT Gramedia Pustaka Utama, 2002), 590.

${ }^{15}$ Eni Lestarina et al., "Perilaku Konsumtif Di Kalangan Remaja," JRTI (Jurnal Riset Tindakan Indonesia) 2 (2017).

${ }^{16}$ Rina Ekaningdyah Anggarasari, “Hubungan Tingkat Religiusitas Dengan Sikap Konsumtif Pada Ibu Rumah Tangga," Psikologika: Jurnal Pemikiran dan Penelitian Psikologi 2, no. 4 (January 1997): 15-20.

17 Ridwan Maulana, “Remaja Dan Perilaku Konsumtif,” Kompasiana. 
Masalah yang muncul kemudian adalah usia remaja adalah usia sekolah dan bukan usia kerja. Artinya remaja belum memiliki uang atau penghasilan sendiri. Mungkin ada orangtua yang mampu untuk memberikan apa yang diminta oleh anak-anak remajanya, namun tidak sedikit orangtua yang tidak mampu. Orangtua yang secara bebas tanpa bimbingan dan arahan memberikan apa yang diminta anaknya tentu menyebabkan remaja lebih konsumtif dengan pemikiran tinggal minta orangtua. Ada juga remaja yang bekerja sambil sekolah, namun tidak dengan serta merta membelanjakan uang secara berlebihan dapat dibenarkan. Remaja harus tetap diajarkan untuk hidup sederhana dan berpuas diri dengan apa yang dimiliki, membeli sesuatu karena memang benar-benar merupakan kebutuhan dan bukan karena keinginan. Remaja juga dapat diajar untuk menabung, menata kehidupannya, bahkan jika berlebihan dapat membantu sesama yang berkekurangan. Jangan sampai karena mereka menginginan untuk membelanjakan sesuatu tetapi karena tidak memiliki uang lalu mereka mulai melakukan hal-hal yang tidak benar, misalnya mencuri.

\section{Gaya Hidup Materialisme}

Gaya hidup materialistis atau materialisme adalah pandangan hidup yang sematamata hanya mencari kesenangan dan kekayaan/kebendaan dimana semuanya merupakan satu-satunya tujuan atau nilai tertinggi. Materialisme seringkali mengesampingkan nilainilai rohani. ${ }^{18}$ Gaya hidup ini merupakan salah satu tantangan bagi para remaja di dalam perubahan zaman. Materialisme bukanlah hanya sekedar memiliki kekayaaan atau harta yang berlimpah tetapi juga sesuatu yang berasal dari hasrat, prioritas, fokus yang sebenarnya tidak diajarkan di dalam kehidupan Kristen.

Materialisme dapat diartikan sebagai paham yang menyatakan bahwa kepemilikan materi menandakan kebahagiaan. Sebaliknya, kebahagiaan ditandai adanya materi. Tidak ada kebahagiaan kecuali adanya kepemilikan dan interaksi dengan materi mulai yang sederhana hingga mewah. Dengan begitu materialisme mengingkari bahwa kebahagiaan dapat diperoleh dari kontemplasi religi, interaksi sosial, ataupun aktualisasi dan realisasi potensi diri dalam menjalani kehidupan. ${ }^{19}$

Gaya hidup materialisme akan sangat mempengaruhi perkembangan anak dan remaja karena kemudian mereka akan menilai diri mereka berdasarkan apa yang mereka miliki. Gaya hidup ini menciptakan persaingan materi dan memicu lahirnya individu yang tamak. Hal ini juga akan berdampak buruk pada kejiwaan dimana ditemukan bahwa banyak anak dan remaja mengalami masalah kesehatan jiwa karena terikat dengan barang, mode, atau pakaian terbaru atau barang elektronik. ${ }^{20}$

Anak-anak seharusnya tidak dieksploitasi tetapi sebaliknya harus didampingi. Memang tidak mudah untuk melindungi mereka dari masuknya beragam informasi tetapi orang dewasa sebagai salah satu pihak yang seharusnya paling bertanggungjawab terhadap tingginya level pemasaran produk komersial pada anak-anak. Mereka juga seharusnya lebih teguh untuk menolak semua permintaan yang tidak masuk akal dari anak-anak. Dampak dari semua ini lagi-lagi pada masalah mental anak-anak dan remaja karena harus memenuhi rasa ingin memiliki yang berlebihan (posesif). Penelitian baik di dalam negeri maupun di Indonesia mendukung adanya gaya hidup materialistis ini dimana banyak orang akan menghabiskan banyak uang saat perayaan hari raya (Natal maupun Lebaran). Materialisme

${ }^{18}$ Gabriel Bobby, "Pragmatisme, Materialisme, Dan Hedonisme ," Kompasiana.

${ }^{19}$ Lailatul Fitriyah, "Jangan Terlalu Materialistik! Materialisme Sebagai Tolak Ukur Kepuasan Hidup," Fakultas Psikologi Universitas Wisnuwardhana Malang 20, no. 1 (2016): 1-8.

${ }^{20}$ Fransiska Mulyono, "Materialisme: Penyebab Dan Konsekuensi," Bina Ekonomi Majalah Ilmiah Fakultas Ekonomi Unpar 15, no. 2 (2011): 44-58. 
ini mengandung dua potensi yang seimbang antara negatif maupun positif. Sebagian kalangan melapisi materialisme ini dengan nilai-nilai non-material guna mencegah potensi negatif yang mungkin ditimbulkannya. ${ }^{21}$

\section{Gaya Hidup Permisif (Serba Boleh)}

Pola asuh permisif adalah suatu pola asuh yang kurang membimbing dan mengarahkan anak, anak diberikan kebebasan sepenuhnya untuk berbuat semaunya tanpa ada kontrol dari orangtua. ${ }^{22} \mathrm{Hal}$ ini dapat terjadi dalam perubahan zaman akibat dari paham kebebasan yang diagung-agungkan. Orang-orang berdalih bahwa dalam perubahan zaman saat ini, manusia berhak melakukan segala sesuatu yang diinginkannya.

Jika mengacu pada pengertian di atas, maka gaya hidup permisif menunjukkan tidak adanya lagi aturan yang melarang untuk melakukan sesuatu hal karena semua diperbolehkan. Misalnya boleh bergaya apa saja, boleh berbelanja apa saja, boleh menggunakan uang untuk apa saja, dan boleh berperilaku apa saja sesuka hati untuk hal-hal yang memang diinginkan. Salah satu hal yang menyebabkan adanya perilaku permisif pada remaja adalah karena pola asuh orangtua. Orangtua yang sejak kecil menerapkan pola asuh permisif, akan menghasilkan anak-anak yang juga memiliki pola pikir dan perilaku yang permisif. $^{23}$

Bahaya besar bagi gaya hidup permisif ini adalah membolehkan segala sesuatu tanpa ada batasan seperti norma/nilai-nilai etika, moral, dan agama. Bisa jadi sampai pada ketiadaannya batas antara yang privacy dan yang umum. Seluruh segi kehidupan terbuka, bisa jadi sesuatu yang dulunya dilarang atau dianggap tabu, sekarang diperbolehkan dan tidak lagi tabu. Hingga dapat juga terjadi manusia mulai membebaskan dirinya dari hal-hal dianggap mistis dan dianggap tidak masuk akal (irasional) kepada hal-hal yang rasional (dapat dilihat/dibuktikan).

Berdasarkan penjelasan tentang ketiga gaya hidup di atas, dapat dilihat bahwa sebenarnya ketiganya saling terkait satu dengan yang lain. Misalnya saja gaya hidup permisif yang serba boleh dapat mempengaruhi seseorang untuk bersikap konsumtif dan materialis, boleh berbelanja apa saja yang penting senang (permisif) dan boleh memiliki apa saja, tidak peduli bagaimana cara untuk mendapatkannya karena itu adalah sebuah kebanggaan tersendiri (materialistis). Atau jika seseorang memiliki gaya hidup materialistis maka demi mendapatkan sesuatu sekalipun harus mengeluarkan uang dalam jumlah yang tidak sedikit akan tetap dilakukan karena berpedoman pada gaya hidup konsumtif yang penting senang tanpa peduli apakah yang dibeli tersebut benar-benar merupakan kebutuhan ataukah hanya keinginan semata.

Akibat dari perubahan zaman yang ditandai dengan perubahan gaya hidup remaja karena tidak ingin dinilai ketinggalan zaman atau tidak mengikuti trend. Remaja cenderung lebih banyak berfokus pada dirinya sendiri, lebih senang memuaskan dirinya sendiri, tidak kuat menghadapi masalah (menyebabkan ada remaja yang bunuh diri), lebih mengikuti apa yang dikatakan oleh iklan/orang lain tentang gaya hidup tertentu. Terlibat dalam minum minuman keras/alkohol, narkoba, dan lain sebagainya. Akibat lebih jauh adalah banyak remaja yang mengalami gangguan syaraf pada otak, gangguan mental, dan terkena HIV/ AIDS. ${ }^{24}$

${ }^{21}$ Akhmad Jayadi et al., "Materialisme Sebagai Penghambat Pembangunan Kesejahteraan Sosial" 2 (2019): 167-171.

${ }^{22}$ Salwa Muin, "Peran Pola Asuh Permisif, Iklim Sekolah, Dan Motivasi Berprestasi Terhadap

Perilaku Membolos Siswa," PSIKOPEDAGOGIA 4, no. 2 (2015): 93-103.

${ }^{23}$ Agoes Dariyo, Psikologi Perkembangan Remaja (Bogor: Ghalia Indonesia, 2004), 65.

${ }^{24}$ Bella, "Gaya Hidup Remaja Zaman Sekarang," Kompasiana. 
Penelitian yang dilakukan oleh Neng Kokom Komariah, dkk., menunjukkan bahwa perubahan gaya hidup remaja berpengaruh terhadap perilaku menyimpang remaja, artinya semakin tinggi perubahan gaya hidup maka akan semakin tinggi pula perilaku melanggar norma di masyarakat. ${ }^{25}$ Pergeseran gaya hidup anak juga diteliti oleh Desi Astuti, dkk., yang dihubungkan dengan kontribusi orangtua dalam hal ini tentang pola asuh, hasilnya adalah pola asuh permisif paling banyak memberikan kontribusi terhadap bergesernya gaya hidup anak. $^{26}$

Pertanyaan penting adalah mengapa remaja memiliki gaya hidup seperti yang telah diuraikan di atas? Semua ini dapat terjadi karena mereka termasuk remaja Kristen tidak memiliki konsep diri yang benar, yang menjadi pegangan dan penentu di dalam berperilaku. Remaja lebih mengikuti trend, mengikuti tokoh idola, mengikuti pendapat teman-temannya, dan sebaliknya orangtua (keluarga), tokoh agama dan gereja tidak berperan dengan baik dalam mengarahkan dan menjadi teladan. Agus Prihanto menegaskan, pemuda dan remaja membutuhkan sosok atau figur yang bisa diteladani karena kebanyakan mereka tidak menemukan keteladanan tersebut di rumah mereka. ${ }^{27}$ Mereka tidak menemukan keteladanan tersebut dari orangtua dan juga tidak menemukan orang lain yang patut diteladani dalam pergaulan mereka maka sebenarnya mereka terus mencari orang yang dapat menjadi contoh bagi kehidupan mereka. Oleh karena itu dalam menghadapi perubahan zaman, sangat diperlukan penanaman konsep diri yang benar sehingga remaja tidak mudah terpengaruh dengan berbagai bentuk perilaku yang sesungguhnya tidak sesuai dengan norma terlebih dalam hal ini tidak sesuai dengan kebenaran Firman Tuhan.

\section{Konsep Diri Remaja}

Remaja seringkali didefinisikan sebagai periode transisi antara masa anak-anak ke masa dewasa. ${ }^{28}$ Masa remaja adalah masa transisi yang menghubungkan masa kanak-kanak dan masa dewasa. ${ }^{29}$ Transisi dari masa anak-anak ke masa dewasa ini ditandai dengan adanya perubahan pada aspek fisik, psikis, dan psikososial. Secara kronologis usia remaja berkisar 12/13-21 tahun dan menurut Erikson pada masa ini untuk menjadi dewasa maka remaja akan melalui masa krisis karena remaja sedang berusaha untuk mencari identitas diri (search for self-identity)..$^{30}$

Remaja yang berusaha mencari jati dirinya (selfidentity) lebih lanjut menurut Erikson, diperhadapkan dengan berbagai pertanyaan menyangkut keberadaan dirinya, siapa saya, akan menjadi apa saya, apa peran saya dalam keluarga, masyarakat, dan dalam kehidupan beragama. Jika remaja berhasil memahami dirinya, maka dia akan menemukan jati dirinya dan memiliki kepribadian yang sehat. Namun sebaliknya apabila gagal, maka remaja akan mengalami kebingungan atau kekacauan (confusion), kurang dapat menyesuaikan diri, baik terhadap dirinya maupun terhadap orang lain. ${ }^{31}$

${ }^{25}$ Neng Kokom Komariah, Dasim Budimansyah, and Wilodati Wilodati, "Pengaruh Gaya Hidup Remaja Terhadap Meningkatnya Perilaku Melanggar Norma Di Masyarakat," SOSIETAS 5, no. 2 (September 2015).

${ }^{26}$ Desi Astuti, Karim Suryadi, and Siti Nurbayani K, "Kontribusi Orang Tua Dalam Proses Pergeseran Gaya Hidup Anak," SOSIETAS 8, no. 1 (August 2018).

${ }^{27}$ Agus Prihanto, "Peran Proses Mentoring Pemimpin Kaum Muda Bagi Perkembangan Pelayanan Pemuda Di Gereja," Jaffray 16, no. 2 (2018): 198-212, https://ojs.sttjaffray.ac.id/JJV71/article/view/258.

${ }^{28}$ Sarlito Wirawan Sarwono, Psikologi Remaja (Jakarta: PT Grafindo Persada, 2003), 2.

${ }^{29}$ John W. Santrock, Adolescence (Jakarta: Airlangga, 2003), 3.

${ }^{30}$ Dariyo, Psikologi Perkembangan Remaja. 14.

${ }^{31}$ Yusuf, Psikologi Perkembangan Anak Dan Remaja. 188. 
Individu yang memiliki identitas diri salah satunya ditandai dengan memiliki karakteristik yaitu konsep diri. Konsep diri adalah gambaran diri tentang aspek fisiologis (warna kulit, betuk tubuh, tinggi badan, wajah-cantik, tampan, biasa) maupun psikologis (kebiasaan, kepribadian, watak, sifat-sifat, kecerdasan, minat bakat) yang berpengaruh pada perilaku individu dalam penyesuaian dengan orang lain. Sejauh mana individu mampu untuk menerima segala kelebihan dan kekurangan dirinya maka hal itu akan membentuk sebuah konsep diri. Apabila mampu menerima maka akan terbentuk konsep diri yang positif, tetapi jika menolak maka akan terbentuk konsep diri yang negatif. ${ }^{32}$

Perkembangan individu (remaja) selalu dipengaruhi oleh faktor-faktor yang berasal dari dalam dirinya (interen/internal), faktor-faktor dari luar dirinya (eksteren/eksternal), dan gabungan dari kedua faktor tersebut. Faktor dari dalam seperti faktor keturunan (hereditas) dan minat sedangkan faktor dari luar adalah yang menyangkut aspek lingkungan fisik (sarana dan fasilitas, letak geografis, cuaca, iklim, dan sebagainya) dan aspek lingkungan sosial (keluarga, teman, lembaga pendidikan, lembaga agama, lembaga kesehatan, dll). Dengan demikian maka semua yang terkait dalam perkembangan remaja perlu bekerja sama sehingga individu (remaja) mampu untuk membentuk konsep diri yang benar.

Konsep diri adalah pandangan diri tentang diri sendiri yang memiliki tiga dimensi yaitu pengetahuan tentang diri sendiri, pengharapan tentang diri sendiri, dan penilaian tentang diri sendiri. Ketiga dimensi ini dapat dijelaskan sebagai berikut: ${ }^{33}$ pertama, pengetahuan tentang diri. Apa yang kita ketahui tentang diri sendiri adalah pertanyaan permulaan di dalam upaya untuk memiliki sejumlah pengetahuan tentang diri sendiri. Daftar panjang dapat dibuat berkaitan dengan jenis kelamin, kebangsaan, suku, jenis pekerjaan, dan sebagainya. Dengan daftar itu lalu mengidentifikasi diri dengan kelompok sosial tertentu yang memberi informasi yang kemudian masuk ke dalam potret diri-mental. Keadaan ini dapat berubah sesuai dengan kelompok dimana seseorang mengidentifikasikan diri. Misalnya pandai atau tidak pandai, dan lain-lain.

Kedua, harapan tentang diri. Setelah memiliki sejumlah pandangan tentang diri, maka akan punya pandangan lain, yaitu tentang kemungkinan menjadi apa di masa mendatang. Pengharapan ini merupakan konsep diri ideal yang mungkin sama tetapi juga berbeda pada setiap orang. Mungkin ada yang memiliki gambaran bahwa di masa depan dirinya memakai jaket yang bagus lalu berdiri dan mengajar di depan kelas dengan jumlah murid yang banyak, tinggal di rumah yang besar dan garasi dipenuhi mobil yang mewah, dan sebagainya. Apapun harapan itu akan mendorong untuk menuju masa depan dan memandu bagaimana perjalanan menuju masa depan.

Ketiga, penilaian tentang diri. Penilaian tentang diri sendiri mencakup saya dapat menjadi apa (pengharapan bagi diri sendiri) dan saya seharusnya menjadi apa (standar bagi diri sendiri). Hasil pengukuran disebut sebagai rasa harga diri yaitu seberapa besar seseorang menyukai diri sendiri. Semakin besar ketidaksesuaian antara gambaran diri dan gambaran tentang diri yang seharusnya, maka akan semakin rendah harga diri. Mereka yang hidup sesuai dengan standar dan harapan, yang menyukai dirinya dan apa yang dikerjakan, akan kemana dirinya akan memiliki rasa harga diri yang tinggi. Sebaliknya, jika terlalu jauh dari standar dan harapan, maka akan memiliki rasa harga diri yang rendah. Evaluasi/penilaian tentang diri merupakan komponen konsep diri yang sangat kuat.

Jallaludin Rakhmat mengungkapkan lima tanda orang yang memiliki konsep diri yang positif, yaitu ia yakin akan kemampuannya mengatasi masalah, ia merasa setara

\footnotetext{
32 Dariyo, Psikologi Perkembangan Remaja. 80.

${ }^{33}$ James F. Calhoun and Joan Ross Acocella, Psikologi Tentang Penyesuaian Dan Hubungan Kemanusiaan (Semarang: IKIP Semarang Press, 1995), 67.
} 
dengan orang lain, ia menerima pujian tanpa rasa malu, ia menyadari, bahwa setiap orang mempunyai berbagai perasaan, keinginan, dan perilaku yang tidak seharusnya disetujui mayarakat, dan ia mampu memperbaiki dirinya karena ia sanggup mengungkapkan aspekaspek kepribadian yang tidak disenanginya dan berusaha mengubahnya. ${ }^{34}$

Konsep diri yang diharapkan dimiliki oleh remaja adalah konsep diri yang positif. Untuk itu dasarnya adalah penerimaan diri. Orang yang dengan konsep diri positif dapat memahami dan menerima sejumlah fakta yang sangat bermacam-macam tentang dirinya sendiri, menerima diri apa adanya. Konsep ini berasal dari hasil interaksi dengan orang lain baik orangtua, teman, dan masyarakat. ${ }^{35}$

\section{Konsep Diri Remaja Kristen}

Dampak perubahan zaman terlihat jelas tidak hanya terjadi pada remaja-remaja lain di luar sana, tetapi juga berdampak pada anak-anak, remaja, dan juga orang-orang percaya lainnya yang ada di dalam gereja. Dalam hal ini orangtua dan gereja perlu sadar sehingga tidak hanya tinggal diam karena berpikir tidak mungkin ada dampak yang buruk terhadap remaja Kristen, apalagi jika merasa sudah cukup dalam memberikan pengajaran-pengajaran tanpa pendampingan dan teladan. Masalah muncul ketika gereja kehilangan remaja karena tidak lagi ada anak-anak yang sungguh-sungguh hidup di dalam pengenalan dan takut akan Tuhan. Namun sebagai individu, remaja juga harus belajar tentang apa yang benar sehingga tidak ikut terjerumus dalam gaya hidup yang tidak sesuai dengan Firman Tuhan. Jadi penanganan untuk dampak perubahan zaman melalui pembentukan konsep diri yang benar tidak hanya dikerjakan secara sepihak tetapi melibatkan dua pihak, yaitu remaja itu sendiri dan juga lingkungan dimana remaja itu ada.

Masa pencarian identitas diri dan masa dimana timbul banyak pertanyaan di dalam diri remaja hingga terbentuknya konsep diri yang positif adalah pergumulan bersama. Dari satu sisi adalah baik jika remaja bertanya dan mencari identitas diri dan membentuk konsep dirinya sendiri, karena dengan demikian akan menghasilkan iman mereka sendiri, dan bukan sekedar meminjam iman dari perkataan orang lain. Ini jelas merupakan dasar yang baik. Namun adalah lebih baik jika orangtua dan gereja ikut membimbing anak-anak muda, mendorong adanya diskusi dan pemahaman tentang panduan moral, memancing dan bukan memaksa atau mendesak. Pemaksaan hanya akan menghasilkan penolakan terhadap gereja dan iman Kristen ataupun diterima tetapi tidak sungguh serius di dalamnya. Hal ini tentu saja jauh dari kedewasaan iman yang diharapkan. Oleh karena itu orangtua dan gereja harus dapat memberikan pengaruh yang positif pada remaja yang mudah dipengaruhi ketika mereka mulai mengalami pergumulan untuk mencari identitas diri dan mancari panduan untuk pegangan hidup. ${ }^{36}$

Remaja saat ini cenderung memiliki iman yang dangkal karena dasar iman itu dibangun dan dipinjam dari orangtua atau kakek-nenek mereka. Akibatnya, setelah mereka jauh dari rumah, mereka sangat mudah mengkompromikan iman mereka karena iman mereka tidak memiliki akar yang dalam, dan ketika ada dalam suatu masalah maka mereka secara rohani belum siap menghadapi dan mengatasinya. ${ }^{37}$

Kebutuhan akan agama dalam artian iman yang diyakini oleh pikiran, diresapkan oleh perasaan dan dilaksanakan dalam tindakan, perbuatan, perkataan dan sikap, sesungguhnya adalah merupakan kebutuhan manusia sejak lahir. Remaja yang berhadapan

\footnotetext{
${ }^{34}$ Jalaluddin Rakhmat, Psikologi Komunikasi (Bandung: Remaja Rosdakarya, 1993), 99-106.

${ }^{35}$ Ibid. 71-91.

36 Paul D. Meier., dkk, Pengantar Psikologi Dan Konseling Kristen (Yogyakarta: Andi Offset,

${ }^{37}$ Ibid.
} 2004), 41. 
dengan hal-hal yang tidak mengindahkan kaidah moral dan agama perlu mempunyai dasar keagamaan dan keimanan. Oleh karena itu penanaman nilai-nilai moral dan agama serta nilai sosial dan akhlak kepada manusia sejak dini khususnya para remaja sangat diperlukan sehingga dapat mengantisipasi apabila terjadinya pertentangan antara pengetahuan dan keyakinan. ${ }^{38}$

Konsep diri yang benar tentu saja harus dibangun di atas dasar Firman Tuhan. Bagaimana orangtua dapat mambangunnya adalah dengan tidak pernah bosan untuk terusmenerus mengajarkan kepada remaja. Firman Tuhan jelas mengatakan bahwa pengajaran tidak hanya terjadi satu atau dua kali tetapi secara berulang-ulang perlu diberikan (Ulangan 6:7). Berarti sebagai orangtua maupun gereja tidak boleh sekalipun merasa bosan apalagi putus asa dan memutuskan untuk berhenti memberikan pengjaran-pengajaran yang benar kepada remaja. Paling tidak apa yang telah ditabur akan membekas di dalam diri mereka, dan selanjutnya kekuatan Roh Kudus lah yang menjaga, mengubahkan, dan memelihara apa yang telah ditabur di dalam diri anak-anak. Sekali lagi memang tidak mudah untuk melakukan ini semua tetapi mestinya senantiasa diingat bahwa ada kuasa yang tak terlihat yang sedang bekerja bersama-sama karena itulah kerinduan Allah agar semua beroleh keselamatan (Yoh. 3:16; II Ptr. 3:9).

Keselamatan bukan hanya milik orang dewasa, tetapi juga milik mereka yang berusia remaja. Perhatian terhadap mereka perlu ditingkatkan. Remaja tidak lagi menjadi kelompok yang diabaikan tetapi justru mendapatkan perhatian dan penanganan serius karena mereka merupakan penerus yang diharapkan akan tetap dapat memberkati banyak orang terlebih memuliakan Tuhan lewat kehidupan mereka. Pendekatan yang lebih bersahabat perlu diusahakan sehingga remaja juga bisa merasa nyaman saat harus mengungkapkan apa yang dirasakannya karena tidak jarang masalah komunikasi menjadi kendala antara orang dewasa dan anak remaja. Orangtua yang terlalu kaku atau juga remaja yang tidak mau terbuka merupakan persoalan yang banyak ditemui.

Penelitian tentang pola komunikasi dalam keluarga menunjukkan hasil bahwa keluarga yang memiliki remaja yang agresif dan anti sosial maka pola yang berlaku adalah ayah yang pura-pura memegang kuasa jika kedua orangtua di depan umum, tetapi pada kesempatan lain si ibu tidak menghargai suaminya. Remaja yang anti sosial akan berpurapura tuli ketika kedua orangtuanya hadir. Studi lain menyebutkan bahwa keluarga-keluarga yang memiliki anak-anak dengan integrasi kepribadian yang baik menunjukkan komunikasi antarpribadi yang lebih langsung, memiliki orientasi pada tugas yang lebih efisien, memiliki peranan yang lebih jelas dari pihak orangtua, dan jarak psikologis yang lebih kecil daripada keluarga-keluarga yang memiliki anak dengan kemampuan menyesuaikan diri yang rendah. ${ }^{39}$

Perkembangan masyarakat modern yang berubah begitu cepat menjadi salah satu penyebab perbedaan pengalaman budaya (differential cultural content) antara orangtua dengan remaja. Pada kenyataannya orangtua seringkali kesulitan untuk membimbing anakanaknya. Konflik pun tidak jarang terjadi karena kedua generasi ini diasuh dalam situasi lingkungan sosial yang berbeda. ${ }^{40}$ Apa yang terjadi pada pola komunikasi dalam keluarga juga terjadi di dalam gereja. Semua komponen orang dewasa dalam gereja juga harus membangun komunikasi yang terbuka, sehingga dapat menjadi sahabat yang baik bagi remaja. Tentunya sama seperti di dalam keluarga rasa saling menghormati tetap harus dimiliki antara orang dewasa dan remaja di gereja.

30.

${ }^{38}$ H. Panut Panuju and Ida Umami, Psikologi Remaja (Yogyakarta: PT Tiara Wacana, 1999), 29-

${ }^{39}$ Meier., dkk, Pengantar Psikologi Dan Konseling Kristen. 44-45.

${ }^{40}$ Yusuf, Psikologi Perkembangan Anak Dan Remaja. 187. 
Peran orangtua dan juga dari diri remaja sendiri, harus memulai untuk membangun suatu model komunikasi yang baik sehingga persoalan-persoalan yang selama ini ada dapat diatasi atau paling tidak dikurangi dampaknya. Konsep diri yang positif dalam diri setiap remaja akan lebih mudah dibangun dalam keluarga/gereja yang saling menghormati, saling mengasihi, dan saling mendukung. Selain orangtua, maka teman juga berperan penting dalam pembentukkan konsep diri remaja. Remaja terkadang tidak mampu untuk memilih yang benar karena takut dijauhi atau dikatakan tidak mengikuti perkembangan zaman. Akibatnya mereka lebih memilih untuk kompromi, padahal mungkin saja jauh di lubuk hati mereka pengetahuan akan kebenaran itu mereka akui, hanya saja untuk melaksanakannya mereka tidak cukup kuat.

Masa kanak-kanak, anak lebih senang untuk mengikuti apa yang menjadi harapan orangtua, namun ketika sudah beranjak remaja biasanya kesetiaan itu akan bergeser dari orangtua kepada teman sekelompok. Pada umumnya remaja akan lebih menggunakan moral teman kelompok. ${ }^{41}$ Pengaruh orang dewasa yang mulai berkurang ketika anak beranjak remaja disebabkan anak telah masuk ke kelompok teman sebaya dalam ragka mencapai perkembangan otonominya (kemandirian). Kelompok teman sebaya dipandang lebih dapat menawarkan reward (ganjaran) sosial yang lebih menarik dibandingkan dengan keluarga. ${ }^{42}$ Apa yang dianggap baik atau tidak baik oleh teman/kelompok maka itu yang dipegangnya, padahal belum tentu demikian. Persoalan-persoalan (merokok, bertato, tawuran, miras, narkoba,dll) remaja seringkali dimulai dari mengikuti teman/kelompok dan ini lagi-lagi karena remaja tidak memiliki konsep diri sebagai pegangan untuk bertindak akibatnya mereka sangat mudah untuk dipengaruhi.

Teman yang baik seharusnya dapat membawa pengaruh yang baik. Ini adalah kualitas pertama yang seharusnya dimiliki oleh seorang teman/sahabat. Selanjutnya setia, yaitu benar-benar ada dalam segala kondisi bukan munafik atau malah meninggalkan saat susah/sulit. Karakter berikut adalah sekalipun dekat tapi tetap bersikap santun dan perhatian dan yang terakhir bersikap jujur apabila mendapati teman/sahabatnya berbuat salah (berani menegur/menyatakan kesalahan dengan kasih). ${ }^{43}$

Remaja perlu selektif dalam memilih teman, karena tidak semua teman dapat membawa kebaikan. Jika salah dalam memilih teman, maka ada kemungkinan remaja tersebut akan salah dalam membentuk konsep diri yang benar karena pengaruh teman yang besar/kuat. Persoalan lainnya yaitu jika remaja juga sangat mudah untuk mengikuti teman/kelompok, maka hal ini sebenarnya dapat dipakai sebagai pijakan untuk memberi pengaruh yang baik dimulai dari satu orang dengan harapan akan menulari kebaikan kepada remaja yang lain.

Segala upaya untuk menolong remaja memiliki konsep diri yang positif/baik dapat diupayakan melalui orangtua/gereja dan teman-teman, tetapi adalah jauh lebih baik jika hal itu datang dari diri remaja sendiri. Tidak dapat disangkal bahwa remaja tetap mendapatkan semua itu melalui proses melihat dan belajar dari lingkungannya. Sesuatu yang dilandasi oleh motif internal biasanya akan lebih bertahan dibandingkan karena motif eksternal. Artinya bahwa remaja perlu mengalami sendiri perjumpaan dengan Tuhan, sehingga konsep dirinya itu benar-benar tertanam dan melekat dalam dirinya, tidak mudah tergoncangkan oleh hal apapun.

Fakta adanya keluarga yang tidak bisa menjadi wadah pembentukan konsep diri yang baik, ada juga teman sebaya remaja yang tidak dapat membawa pengaruh positif.

${ }^{41}$ Meier., dkk, Pengantar Psikologi Dan Konseling Kristen. 47-48.

42 Yusuf, Psikologi Perkembangan Anak Dan Remaja. 189.

${ }^{43}$ Andrew Brake, Hidup Bijak Di Dunia Yang Bodoh, Menggali Sumber Hikmat Sejati Dari Alkitab

(Bandung: Kalam Hidup, 2015), 138-148. 
Untuk itu remaja perlu dibawa secara pribadi untuk terlebih dahulu mengenal Allah Sang Pencipta dengan benar sehingga mereka juga dapat mengenal diri mereka dengan benar. Ketertarikan pada hal-hal yang rohani dan bersifat kekal harus lebih dominan dalam diri mereka ketimbang yang hanya merupakan kesenangan sementara. Mungkin dapat dicontohkan bahwa lebih baik menghadiri ibadah daripada jalan-jalan tanpa tujuan, lebih baik membaca dan belajar Firman Tuhan daripada menghabiskan waktu dengan bermain handphone, dan sebagainya. Hikmat Allah sungguh sangat dibutuhkan dalam hal ini untuk memilih yang tepat.

Manusia tidak mampu untuk menemukan hikmat dan arah kehidupannya, hanya Allah yang dapat memampukan. Oleh karena itu manusia perlu mencari-Nya, takut akan Allah dan menghormatinya, bersikap rendah hati untuk mau mengarahkan hidup hanya pada-Nya dan memiliki tujuan hidup yaitu untuk menyenangkan-Nya dan bukan sebaliknya menyenangkan diri sendiri. Rasa takut akan Tuhan akan menuntun untuk menjalani hidup dengan lebih berhikmat, artinya bahwa hidup manusia dipimpin oleh Dia dan bukan oleh apa yang dianggap oleh orang lain berhikmat. ${ }^{44}$

Remaja perlu hikmat Tuhan, sehingga tidak berjalan mengikuti apa yang menjadi keinginan hatinya sendiri. Remaja perlu untuk memberi diri diubahkan dan dituntun oleh kuasa Roh Kudus. Rasa takut akan Tuhan memegang peranan penting. Remaja perlu menyadari bahwa Tuhan selalu ada bersama dengan dirinya. Tuhan mengerti dan memahami apa yang dihadapinya dan sungguh sangat mengasihi dirinya. Hal ini akan mendorongnya untuk selalu bertanya sebelum bertindak karena menyadari bahwa Tuhan ada bersamanya dan dia sungguh hormat akan kehadiran Tuhan yang menyertai langkahlangkahnya.

Apabila membandingkan diri dengan oranglain mungkin juga remaja akan mengalami kekecewaan karena mereka tidak punya landasan berpikir yang benar. Kenyataan yang terjadi bahwa tetap berdiri dalam kebenaran dalam setiap keputusan kehidupan, sepertinya tidak membawa kepada keuntungan tetapi kerugian. Misalnya remaja yang mengikuti perilaku teman-temannya yang tidak benar cenderung lebih menjadi populer, cenderung lebih disukai, lebih memiliki banyak teman, bahkan tidak jarang disanjung. Mereka yang memiliki gaya hidup konsumtif, materialis, dan permisif sepertinya lebih menikmati banyak tawa dan kesenangan.

Sekali lagi hikmat Allah yang seringkali ketika diikuti tampak tidak masuk akal. Tidak serta merta menunjukkan hasil karena membutuhkan kesabaran yang tinggi, dan membutuhkan banyak pertimbangan dan nasihat dari orang lain terlebih Firman-Nya, haruslah tetap menjadi pilihan bagi remaja. Remaja harus tetap percaya pada tuntunan Tuhan dengan segenap hati dan jangan pernah sekalipun bersandar pada pengertiannya sendiri karena cepat atau lambat buah-buah yang baik akibat pilihan bijak yang telah dibuat dengan tuntunan hikmat Allah akan dinikmatinya. Keberhasilan sejati hanyalah keberhasilan yang baik dan benar dalam pandangan Allah. ${ }^{45}$ Memilih hal-hal yang bernilai kekekalan dibandingan dengan yang hanya merupakan kenikmatan sesaat tetapi ujungnya adalah kebinasaan sangatlah bijak. Itulah kehidupan yang dikehendaki Allah untuk dijalani.

Konsep diri yang perlu dibangun selanjutnya adalah menyadarkan remaja bahwa penilaian diri mereka yang benar adalah yang datang dari Tuhan. Mereka diajak kembali untuk melihat dan menilai diri berdasarkan pandangan Dia yang menjadikan semua ada yaitu Tuhan sendiri. Ketika orang percaya mengidentifikasi dirinya dengan hikmat Allah maka dia akan menyadari bahwa: ${ }^{46}$ Tuhan mengenal dirinya jauh dibandingkan dengan dia

${ }^{44}$ Ibid. xii.

45 Ibid. 1-12.

${ }^{46}$ Josh McDowell, “Bagaimana Mengenal Diri Kita? ," Kristen Alkitabiah. 
mengenal dirinya sendiri. Hanya Tuhan yang tahu nilai manusia yang sebenarnya. Manusia jauh lebih berharga daripada hanya sekedar penampilan, kinerja, dan statusnya. Hanya Tuhan yang bisa mengisi hidup manusia dengan kasih, cinta dan arti. Tuhan mengasihi secara penuh. Kasih-Nya tulus, murni, suci, tanpa memandang rupa, orang percaya diidentifikasikan sebagai anak-anak Raja, ahli waris kerajaan Allah (Rm. 8:17). Anak-anak Allah, orang percaya akan lebih berbahagia dengan identitas seperti itu. Begitu dia mengidentifikasikan dirinya dengan sang Raja, maka dia akan menjalani kehidupan sebagai seorang pangeran dan putri raja dan identitasnya sebagai anak Allah akan membuat perbedaan besar dalam bagaimana dia memandangi kehidupannya sendiri, pergumulan, hubungan dengan orang lain, dan dengan Allah.

Demikianlah identitas orang percaya yang sesungguhnya berdasarkan pandangan Tuhan atas dirinya. Memang harus diakui bahwa ada banyak hal yang tidak mungkin diubah dalam diri manusia seperti keadaan fisik (kulit hitam/putih, rambut lurus atau keriting, dan sebagainya). Mungkin ada juga orang yang memandang rendah tentang keberadaan orang lain, akan tetapi ketika seseorang telah belajar bahwa hal itu tidaklah benar karena cukuplah untuk diketahui bahwa Allah menilai dengan sangat tinggi. Manusia cenderung melihat dan menilai dari penampilan luar, tetapi Allah yang sanggup melihat sampai ke dalam hati, hanya Allah yang mampu melihat yang tersembunyi sekalipun ( I Sam. 16:7). Orang percaya adalah warga kerajaan sorga yang sangat dikasihiNya dan ahli waris kerajaan-Nya (Yak. 2:5). Remaja dengan konsep diri yang benar tidak menangisi akan kelemahannya tetapi tetap menganggap itu sebagai hal yang baik dan tetap optimis bahwa dengan kelemahan sekalipun Allah dapat menyempurnakan segala kelemahan tersebut dan memakainya untuk kemuliaan-Nya (2 Korintus 12:9, 10). Sebaliknya kelebihan yang dimiliki bukan sebagai alat kesombongan, tetapi tetap menjadi anugerah Allah untuk dipakai menjadi berkat.

Kesadaran bahwa manusia dinilai sangat tinggi oleh Allah membuat dia lebih menghargai akan diri sendiri dan menjalani hidup berdasarkan penilaian Allah yang tinggi tersebut. Manusia diciptakan dari debu tanah yang tidak berarti tetapi hanya manusia juga yang diciptakan menurut gambar dan rupa-Nya (Kej. 1:26-30; 2:7). Selanjutnya karya penebusan Kristus bagi orang berdosa adalah bukti tertinggi bahwa sebagai orang percaya sangat berharga dan Allah sungguh sangat peduli. Sangat berharga karena telah dibayar dengan darah Kristus yang mahal (I Ptr. 1:19). Tidak ada kasih yang lebih besar dari itu, kasih seorang yang memberikan nyawanya untuk sahabat-sahabat-Nya (Yohanes 10:11; 15:13). Dahulu memang kita adalah orang-orang yang tidak berarti akibat dosa, tetapi di dalam Kristus semua telah diubahkan menjadi berarti. Remaja Kristen harus mendengar dan memahami hal ini dengan baik, sehingga tidak ada seorang pun yang dapat merendahkan dan melemahkan mereka, karena penilaian Allah jauh lebih penting. Tidak perlu lagi menyia-nyiakan waktu hidup, tetapi mau memakai waktu hidup hanya bagi Allah (Flp. 1:21; Flp. 3:7).

Menyadarkan remaja bahwa mereka perlu hikmat Tuhan dalam dunia ini dan mereka dinilai sangat istimewa perlu diikuti dengan keteladan hidup yang benar. Tidak jarang remaja selalu mencari seseorang atau hal tertentu yang dapat menjadi panutan/idolanya. Tokoh-tokoh yang ada di dunia baik yang nyata maupun yang bersifat khayalan dengan berbagai karakter seperti terkenal, disiplin, berani, dan sebagainya sering dipilih juga karena sebagai bentuk pelarian remaja dari kehidupan keluarga yang dirasa tidak memberi perhatian yang cukup baginya. ${ }^{47}$ Oleh karena itu penting sekali untuk menghadirkan tokoh-tokoh yang benar dan menjadi teladan yang benar baik itu dari orangtua maupun gereja (pelayan remaja, hamba Tuhan/pendeta) agar ada role model bagi

${ }^{47}$ Dariyo, Psikologi Perkembangan Remaja. 70. 
remaja yang membantunya dalam menjalani hidup dengan lebih bijak dan lebih bertanggungjawab.

Upaya berikutnya yang perlu diperhatikan ialah pendekatan populis dengan pendidikan humanis-religius. Pendekatan yang populis dengan mengkolaborasikan pendidikan humanis-religius, artinya penekanan dan penanaman nilai serta norma disematkan secara humanis tidak secara frontal. Upaya-upaya yang diusulkan meliputi: pertama, keterlibatan orangtua secara intesif dalam membimbing dan mengarahkan anakanaknya sendiri. Kedua, gereja memiliki tanggungjawab besar dalam mengabdikan diri memberi didikan dan disiplin rohani kepada anak-anak. Ketiga, pendidikan di sekolah yang dapat membentuk karakter siswa tidak cukup melalui kurikulum namun diperlukan perhatian yang besar terhadap pengembangan aspek afektif dan psikomotorik. Keempat, pemerintah bertanggung jawab dalam memberi solusi dalam menyelesaikan kenakalan remaja dengan membentuk lembaga-lembaga khusus yang menangani masalah tersebut. ${ }^{48}$ Pendekatan yang populis dengan mengkolaborasikan pendidikan humanis-religius, artinya penekanan dan penanaman nilai serta norma disematkan secara humanis tidak secara frontal. ${ }^{49}$ Dengan pendekatan ini, diharapkan remaja Kristen dapat dibentuk konsep dirinya untuk semakin lebih baik.

\section{Kesimpulan}

Teladan sejati bagi orang Kristen, dalam hal ini remaja tentu saja hanyalah Yesus. Hal ini karena semua sedang memandang kepada-Nya dan rindu untuk menjadi serupa denganNya. Teladan Yesus nampak di dalam keseluruhan pelayanan-Nya (cara hidup, ajaran-Nya, dan perintah-perintah-Nya). ${ }^{50}$ Remaja harus terus membawa diri kepada Yesus, karena hanya Yesus yang sanggup menolong mereka melewati berbagai tantangan kehidupan sebagai anak-anak muda. Yesus berkuasa atas seluruh alam semesta termasuk juga atas kehidupan semua orang percaya.

Sama seperti Kristus yang bertumbuh dalam anugerah, maka sebagai orang percaya, khususnya remaja Kristen harus terus bertumbuh dalam anugerah-Nya. Bertumbuh dalam anugerah berarti menjadi serupa dengan Kristus. ${ }^{51}$ Manusia perlu mengambil langkah untuk hanya berfokus pada Yesus, mengenal Dia dengan lebih baik. Memang jalan tidak akan selamanya mulus, karena terkadang akan berhadapan dengan jalan menurun, menanjak, berbatu terjal, bahkan jalan yang membutuhkan pengorbanan diri. Namun tetap diingat, bahwa apabila orang percaya sudah bertumbuh di dalam-Nya maka ia perlu membagikan itu kepada mereka lain yang membutuhkan. ${ }^{52}$

Konsep diri yang benar sebagai remaja Kristen telah ditemukan di dalam Yesus (Firman-Nya). Remaja perlu menularkan itu kepada remaja yang lain sehingga semua remaja merasakan anugerah dan boleh menerima keselamatan di dalam Kristus, bahkan bagi seluruh dunia. Remaja tidak lagi menjalani hidup dengan foya-foya, berorientasi pada halhal fana, dan sesuka hati, tetapi sebaliknya menjalaninya dengan lebih bertanggungjawab karena dia memiliki konsep diri yang benar, dia tahu siapa dirinya dan untuk apa adanya di dunia ini. Teruslah bertumbuh untuk menjadi serupa dengan-Nya.

${ }^{48}$ Ezra Tari and Talizaro Tafonao, “Tinjauan Teologis-Sosiologis Terhadap Pergaulan Bebas Remaja," DUNAMIS: Jurnal Teologi dan Pendidikan Kristiani 3, no. 2 (April 2019): 199.

${ }^{49}$ Petrus Marija, Yudhi Kawangung, and Munatar Kause, "Pendekatan Humanis-Relegius Pada Pendidikan Kristen Sebagai Pembentukan Karakter Generasi Milenial ," Jurnal Teruna Bhakti 2, no. 1 (2019).

50 Brake, Hidup Bijak Di Dunia Yang Bodoh, Menggali Sumber Hikmat Sejati Dari Alkitab. 205-259.

${ }^{51}$ Sinclair B. Ferguson, Bertumbuh Dalam Anugerah (Surabaya: Momentum, 2010), 8.

52 Ibid. 143-146. 


\section{Rujukan}

Anggarasari, Rina Ekaningdyah. "Hubungan Tingkat Religiusitas Dengan Sikap Konsumtif Pada Ibu Rumah Tangga." Psikologika: Jurnal Pemikiran dan Penelitian Psikologi 2, no. 4 (January 2, 1997): 15-20. Accessed June 15, 2020. https://journal.uii.ac.id/Psikologika/article/view/8435.

Annisa, Mayang D. "Hubungan Antara Konsep Diri Dengan Kecemasan Umum Pada Remaja Awal." Jurnal Psikologi 10, no. 2 (December 2017): 106-111. Accessed June 15, 2020. https:/ /ejournal.gunadarma.ac.id/index.php.

Astuti, Desi, Karim Suryadi, and Siti Nurbayani K. "Kontribusi Orang Tua Dalam Proses Pergeseran Gaya Hidup Anak." SOSIETAS 8, no. 1 (August 16, 2018). Accessed June 15, 2020. https://ejournal.upi.edu/index.php/sosietas/article/view/12503.

Bella. "Gaya Hidup Remaja Zaman Sekarang." Kompasiana. Last modified October 20, 2018. Accessed June 15, 2020. https://www.kompasiana.com/bella53759/5bcae729ab12ae6f1f3122e4/gaya-hidupremaja-zaman-sekarang.

Bobby, Gabriel. "Pragmatisme, Materialisme, Dan Hedonisme." Kompasiana. Last modified September 7, 2015. Accessed June 15, 2020. https://www.kompasiana.com/gabrielbobby/55edad0c2623bdf40bc10e50/pragmatis me-materialisme-dan-hedonisme.

Brake, Andrew. Hidup Bijak Di Dunia Yang Bodoh, Menggali Sumber Hikmat Sejati Dari Alkitab. Bandung: Kalam Hidup, 2015.

Calhoun, James F., and Joan Ross Acocella. Psikologi Tentang Penyesuaian Dan Hubungan Kemanusiaan. Semarang: IKIP Semarang Press, 1995.

Dariyo, Agoes. Psikologi Perkembangan Remaja. Bogor: Ghalia Indonesia, 2004.

Departemen Pendidikan Nasional. Kamus Besar Bahasa Indonesia. Jakarta: PT Gramedia Pustaka Utama, 2002.

Dominggus, Dicky. "Kemanunggalan Dalam Yohanes 15:7 Sebagai Misi Kontekstual Kepada Penganut Kejawen." VISIO DEI: JURNAL TEOLOGI KRISTEN 1, no. 2 (December 18, 2019): 178-199. Accessed June 15, 2020.

http://jurnal.sttstarslub.ac.id/index.php/js/article/view/53.

Felita, Pamela, Christine Siahaja, Vania Wijaya, Gracia Melisa, Marcella Chandra, and Rayini Dahesihsari. "Pemakaian Media Sosial Dan Self Concept Pada Remaja." Jurnal Ilmiah Psikologi Manasa 5, no. 1 (2016): 30-41. Accessed June 15, 2020.

http:/ / ejournal.atmajaya.ac.id/index.php/Manasa/article/download/184/365/.

Ferguson, Sinclair B. Bertumbuh Dalam Anugerah. Surabaya: Momentum, 2010.

Fitriyah, Lailatul. "Jangan Terlalu Materialistik! Materialisme Sebagai Tolak Ukur Kepuasan Hidup." Fakultas Psikologi Universitas Wisnuwardhana Malang 20, no. 1 (2016): 1-8. http://psikovidya.wisnuwardhana.ac.id/index.php/psikovidya/article/view/11.

Jayadi, Akhmad, Imam Nawawi, Mohammad Wasil, and Mohammad Sabiq. "Materialisme Sebagai Penghambat Pembangunan Kesejahteraan Sosial” 2 (2019): 167-171.

Komariah, Neng Kokom, Dasim Budimansyah, and Wilodati Wilodati. "Pengaruh Gaya Hidup Remaja Terhadap Meningkatnya Perilaku Melanggar Norma Di Masyarakat." SOSIETAS 5, no. 2 (September 18, 2015). Accessed June 15, 2020. https:/ / ejournal.upi.edu/index.php/sosietas/article/view/1527.

Lauer, Roberth H. Perspektif Tentang Perubahan Sosial. Jakarta: PT Rineka Cipta, 2001.

Lestarina, Eni, Hasnah Karimah, Nia Febrianti, Ranny Ranny, and Desi Herlina. "Perilaku Konsumtif Di Kalangan Remaja." JRTI (Jurnal Riset Tindakan Indonesia) 2 (2017).

Listyorini, Sari. “Analisis Faktor-Faktor Gaya Hidup Dan Pengaruhnya Terhadap Pembelian 
Rumah Sehat Sederhana (Studi Pada Pelanggan Perumahan Puri Dinar Mas PT. Ajisaka Di Semarang)." Jurnal Administrasi Bisnis 1, no. 1 (September 30, 2012). Accessed June 15, 2020. https://ejournal.undip.ac.id/index.php/janis/article/view/ 4314.

Marija, Petrus, Yudhi Kawangung, and Munatar Kause. "Pendekatan Humanis-Relegius Pada Pendidikan Kristen Sebagai Pembentukan Karakter Generasi Milenial ." Jurnal Teruna Bhakti 2, no. 1 (2019). Accessed June 13, 2020. http:/ /ejournal.stakterunabhakti.ac.id/index.php/teruna/article/view/36.

Matheus, Jonathan, and Elisabet Selfina. "Peran Pembina Remaja Bagi Perkembangan Perilaku Remaja Di Gereja Kemah Injil Indonesia Tanjung Selor Kalimantan Utara." Jurnal Jaffray 13, no. 1 (January 31, 2015): 1. Accessed June 15, 2020.

https://ojs.sttjaffray.ac.id/JJV71/article/view/3.

Matondang, Sadadohape. "Memahami Identitas Diri Remaja Dalam Kristus Menurut Efesus 2:1-10." Illuminate: Jurnal Teologi dan Pendidikan Kristiani 1, no. 1 (August 2018): 105-124. Accessed June 15, 2020. http:/ /e-journal.sttbaptismedan.ac.id/index.php/illuminate/article/download/2/1.

Maulana, Ridwan. "Remaja Dan Perilaku Konsumtif." Kompasiana. Last modified October 18, 2013. Accessed June 15, 2020.

https://www.kompasiana.com/maulanaridone/552a70ce6ea834ad6c552d01/remajadan-perilaku-konsumtif.

McDowell, Josh. “Bagaimana Mengenal Diri Kita $\square$ ? ." Kristen Alkitabiah. Last modified December 9, 2014. Accessed June 15, 2020.

https://www.kristenalkitabiah.com/bagaimana-mengenal-diri-kita/.

Meier., dkk, Paul D. Pengantar Psikologi Dan Konseling Kristen. Yogyakarta: Andi Offset, 2004. Muin, Salwa. "Peran Pola Asuh Permisif, Iklim Sekolah, Dan Motivasi Berprestasi Terhadap Perilaku Membolos Siswa." PSIKOPEDAGOGIA 4, no. 2 (2015): 93-103. Accessed June 15, 2020.

http://journal.uad.ac.id/index.php/PSIKOPEDAGOGIA/article/download/4477/261 0 .

Mulyono, Fransiska. “Materialisme: Penyebab Dan Konsekuensi." Bina Ekonomi Majalah Ilmiah Fakultas Ekonomi Unpar 15, no. 2 (2011): 44-58. Accessed June 15, 2020. https://media.neliti.com/media/publications/12875-ID-materialisme-penyebab-dankonsekuensi.pdf.

Panuju, H. Panut, and Ida Umami. Psikologi Remaja. Yogyakarta: PT Tiara Wacana, 1999.

Prihanto, Agus. "Peran Proses Mentoring Pemimpin Kaum Muda Bagi Perkembangan Pelayanan Pemuda Di Gereja." Jurnal Jaffray 16, no. 2 (2018): 198-212. https://ojs.sttjaffray.ac.id/JJV71/article/view/258.

Putro, Khamim Zakasih. "Memahami Ciri Dan Tugas Perkembangan Masa Remaja." APLIKASIA: Jurnal Aplikasi Ilmu-ilmu Agama 17, no. 1 (2017): 25-32. Accessed June 15, 2020. http://ejournal.uin-suka.ac.id/pusat/aplikasia/article/viewFile/1362/1180.

Rakhmat, Jalaluddin. Psikologi Komunikasi. Bandung: Remaja Rosdakarya, 1993.

Santrock, John W. Adolescence. Jakarta: Airlangga, 2003.

Sarwono, Sarlito Wirawan. Psikologi Remaja. Jakarta: PT Grafindo Persada, 2003.

Simon. "Peranan Gereja Dalam Menghambat Laju Pertumbuhan Pemakai Narkoba." Jurnal Ilmiah Religiosity Entity Humanity (JIREH) 1, no. 2 (December 23, 2019): 172-186.

Susanto. Potret-Potret Gaya Hidup Metropolis. Jakarta: Kompas, 2001.

Tari, Ezra, and Rinto Hasiholan Hutapea. "Peran Guru Dalam Pengembangan Peserta Didik Di Era Digital." Kharisma: Jurnal Ilmiah Teologi 1, no. 1 (June 3, 2020): 1-13. Accessed June 11, 2020. http://jurnalsttkharisma.ac.id/index.php/Kharis/.

Tari, Ezra, and Talizaro Tafonao. "Tinjauan Teologis-Sosiologis Terhadap Pergaulan Bebas Remaja." DUNAMIS: Jurnal Teologi dan Pendidikan Kristiani 3, no. 2 (April 29, 2019): 199. 
Jurnal Ilmiah Religiosity Entity Humanity (JIREH)

Vol. 2, No. 1, (Juni 2020): 53-69

Yusuf, Syamsu. Psikologi Perkembangan Anak Dan Remaja. Bandung: Rosdakarya, 2002. 